\title{
Natural Rubber Films Incorporated with Red Propolis and Silver Nanoparticles Aimed for Occlusive Dressing Application
}

\author{
Charlene Silvestrin Celi Garcia ${ }^{a}$, Ana Elisa Dotta Maddalozzo ${ }^{a}$, Paulo Miguel Celi Garcia ${ }^{a, c}$, \\ Cristian Padilha Fontoura $^{b}$ (D), Melissa Machado Rodrigues ${ }^{b}$ (D), Marcelo Giovanela ${ }^{b}$ (D), \\ João Antonio Pêgas Henriques ${ }^{a}$ (D), Cesar Aguzzoli ${ }^{b}$,Janaina da Silva Crespo ${ }^{b^{*}}$ (D), \\ Mariana Roesch-Ely ${ }^{a^{*}}$ (iD \\ ${ }^{a}$ Universidade de Caxias do Sul, Instituto de Biotecnologia, Caxias do Sul, RS, Brasil. \\ ${ }^{b}$ Universidade de Caxias do Sul, Área do Conhecimento de Ciências Exatas e Engenharias, Rua \\ Francisco Getúlio Vargas, 1130, 95070-560, Caxias do Sul, RS, Brasil. \\ 'Sociedade Brasileira de Cirurgia Plástica (SBCP), Rua Mato Grosso, 306, Higienópolis, 01239-040, \\ São Paulo, SP, Brasil.
}

Received: September 14, 2020; Revised: December 07, 2020; Accepted: January 14, 2021

In this work, NRL films were enriched with red propolis and silver nanoparticles with the aim of obtaining dressings with bactericide properties. To improve the properties of these materials, plasma treatment was also applied to the films. Cytotoxic effects were evaluated by MTT and agar diffusion assays on secondary and stem cells. Determination of cell behavior on the films were assessed by EDS and FEG-SEM. In general, the plasma modified NRL films presented hydrophilic character, favorable condition for biomedical applications. RBS results showed that silver is probably in nanoparticulate form. MTT assays revealed that non-cytotoxic effects were observed for all the samples extracts. Either the plasma treatment or silver deposition were effective in sterilizing the samples and modifying their surfaces. It was demonstrated in this in vitro study that ADSCs associated with NRL films enriched with propolis should be considered promising for application in the healing of occlusive wounds.

Keywords: natural rubber latex films; plasma treatment; wound dressing; red propolis; silver nanoparticles.

\section{Introduction}

Burnings represent a severe risk to human health, being the third cause of accidental death on a global scale ${ }^{1}$. The lack of skin tissue coverage increases vulnerability to infections and allows microorganism proliferation. As a consequence, functions related to skin protection against infections, lesions and trauma become compromised ${ }^{2}$. In this scenario, biomaterials applied as wound dressings guarantee the integrity of the tissue and its protective function.

Natural rubber latex (NRL) has attracted much attention amongst biomaterials for activating biological healing responses $^{3}$, such as angiogenic activity, which is the ability of healing burns through the promotion of blood vessel formation ${ }^{4}$. Due to this property, it can be used to aid people who suffer from diabetes and the accompanying hardships of wound healing 5 .

A special concern related to burns is the predisposition to secondary infection processes, which is responsible for about $75 \%$ of registered deaths amongst burnt patients ${ }^{6}$. The use of substances that have antibacterial properties in association with latex minimizes infections, like the ones caused by Staphylococcus aureus, commonly found in burnings ${ }^{7,8}$.

*e-mail: jscrespo@ucs.br
Literature has reported the antibacterial activity of red propolis due to its complex and varying chemical composition ${ }^{9}$ which includes flavonoids and aromatic acids, as well as different types of terpenoids ${ }^{10,11}$. It is constituted of exudates from floral shoots and buds of various plants, presenting many benefits to human health, like antioxidant, anti-inflammatory and regenerating properties ${ }^{9-12}$. Red propolis (RP) was chosen to be studied in this work, as it is a product that can be only found in Brazil, so it represents a native resource that can help in public health. Brazil is considered one of the greatest propolis producers in the world due to the large diversity of ecosystems and to the favorable climate ${ }^{13,14}$. Also, there are not many studies about RP in comparison to green propolis (the most commercialized type). Besides differences in the chemical composition of both products, the literature reported that RP presents more toxic activity than the green sort ${ }^{15}$.

The association of latex films to silver guarantees further bactericide character and low toxicity to human cells ${ }^{16,17}$. Silver as a topical antimicrobial agent has been featured in wound dressing applications ${ }^{18-20}$, being useful in the treatment of acute wounds, burns or surgical wounds and effectively accelerating the healing process ${ }^{17}$. Silver is effective against Escherichia coli, one of the most difficult 
microorganisms to treat and found in burning injuries. This type of bacteria has become multi-resistant to antibiotics, the reason why silver is a good option to be used ${ }^{21,22}$. When in nanoparticle or ion form, silver has antimicrobial effects against Gram-positive and Gram-negative bacteria, so it is largely employed in biomedical industry ${ }^{23,24}$.

Besides protection against microorganisms ${ }^{25}$, a desirable feature for occlusive dressing materials is avoidance of fibroblast adhesion, so the removal of the dressing from the wound will not damage the newly generated tissue $e^{26,27}$. In addition, a dressing should be hydrophilic, because it will accelerate scarring process as wound-released exudates are absorbed without compromising the moist environment ${ }^{28}$. Literature has pointed that surfaces of low hydrophilicity encourages growth of bacteria, compromising healing ${ }^{27}$.

Aiming to enhance hydrophilicity, avoidance of cell adhesion and bactericide activity, different processes in this study such as silver nanoparticles (AgNPs) deposition, incorporation of RP and plasma treatment were tested and compared trough the latex samples as promising products. Plasma treatment is a vastly used technique for modifying all classes of materials, sterile packaging and biomedicineaimed products, but it is efficiency has not yet been exploited thoroughly in wound dressing applications ${ }^{29}$. Apart from that, another advantage of plasma-assisted processes is that the modification takes place solely on the surface being treated, while bulk properties, such as mechanical ones, are maintained ${ }^{30}$. In this case, the elastic properties of latex would be maintained and remain ideal for wound dressing, as the limbs could move freely without breaking the polymeric membrane.

In polymers, plasma-assisted processes are used to modify surface properties of great importance in biomaterials ${ }^{31}$, such as wettability, permeability and biocompatibility. When a polymeric material is submitted to plasma treatment, it interacts with the ionized gas environment and generates new functional groups, which are responsible for modifying the aforementioned properties, as plasma active species interact with molecules on the polymer's surface ${ }^{32}$. Apart from benefiting from many biomedically relevant physicochemical properties, plasma treatment can effectively sterilize the treated surface ${ }^{33}$, reason to why the authors chose to use this technique. These treatments are also eco-friendly, so they do not damage the environment.

For the treatment of chronic injuries, the association of autologous stem cells and biomaterials is recommended ${ }^{34}$. The application of autologous adipose derived stem cell (ADSCs) with biocompatible materials can be a promising strategy to assist burn patients who require a large graft area to cover extensive sites and who are limited by the availability of donor $\operatorname{skin}^{35,36}$. Some advantages of working with ADSCs are the large amount of these cells found in our body, the facility to be collected with little risk of morbidity to the donor, presence of plasticity, multipotentiality and capability to differentiate into epithelial tissue, including dermis and epidermis ${ }^{37}$.

In this context, the main goal of this work was to produce NRL films for a possible application as wound dressings. Physico-chemical characterization and biological assays were also carried out to investigate surface properties and the biocompatibility of these films during contact with steam cells and secondary fibroblasts.

\section{Materials and Methods}

\subsection{Natural rubber latex (NRL)}

NRL used to produce the matrix of the films was acquired by Du Latex (São Paulo, Brazil) and is derived from trees of the same clone. A centrifugation process was performed to decrease the amount of allergenic proteins by stabilizing sulfur and ammonium hydroxide. The elastomer belonged to lot LA032618, with a $\mathrm{pH}$ of 10.4 .

\subsection{Red propolis (RP)}

RP from Alagoas State (Northeast region of Brazil) was used in this study. RP was stored in a dry, light exposurefree environment and frozen at $-20{ }^{\circ} \mathrm{C}$ until the extract was prepared. RP samples were milled into a thin powder and $50 \mathrm{~g}$ were mixed into $500 \mathrm{~mL}$ of EtOH- $\mathrm{H}_{2} \mathrm{O} 70 \%-30 \%$ $(\mathrm{v} / \mathrm{v})$. This mixture was brought to mechanical stirring for a period of $24 \mathrm{~h}$ at room temperature and then filtered. The solvent was later evaporated at $37{ }^{\circ} \mathrm{C}$ and freeze-dried. At the end of this procedure, RP was kept at $-20{ }^{\circ} \mathrm{C}$ until analyses were performed.

\subsection{Natural rubber latex films}

NRL films were prepared by shedding $40 \mathrm{~mL}$ of latex in a Petri dish, which was inserted on a furnace (Q317M - Quimis, Diadema, Brazil) for $24 \mathrm{~h}$ at $65{ }^{\circ} \mathrm{C}$, until complete dry. Biological properties are favorable when heat treatment on NRL is conducted between $65-85^{\circ} \mathrm{C}$. At this temperature range, rubber particles coagulate faster during the evaporation of latex byproducts, thus supplying a greater presence of phospholipids and proteins not bonded to rubber particles. These proteins are responsible for angiogenic activity in late ${ }^{38}$, so biological properties are favored.

\subsection{Natural rubber latex films containing red propolis (NRL-RP)}

$\mathrm{RP}$ was diluted in $2 \mathrm{~mL}$ of $\mathrm{EtOH}-\mathrm{H}_{2} \mathrm{O} 50 \%(\mathrm{v} / \mathrm{v})$, and then added to $38 \mathrm{~mL}$ of NRL. The mixture remained on a furnace (Q317M - Quimis, Diadema, Brazil) for $24 \mathrm{~h}$ at $65^{\circ} \mathrm{C}$ until complete dry. Figure 1 displays a flow chart of how RP was prepared until incorporation into NRL.

\subsection{Plasma treatment}

The NRL and NRL-RP films were inserted into a vacuum chamber (homemade), which was evacuated up to $3.0 \times 10^{-2}$ mbar. The gases used for plasma discharge were oxygen (Linde, Brazil, purity of $99.9992 \%$ ) and hydrogen (Linde, Brazil, purity of $99.9992 \%$ ) in a $1: 1$ ratio. Work pressure of 1.0 mbar was used. To generate the electric potential, a $13.56 \mathrm{MHz}$ radiofrequency source (Tokyo Hy-Power RF-300, Japan) was applied with $30 \mathrm{~W}$ of power. The process was carried out for $10 \mathrm{~min}$. It is important to highlight that input power must be kept at the minimum possible value, once temperature may ignite 


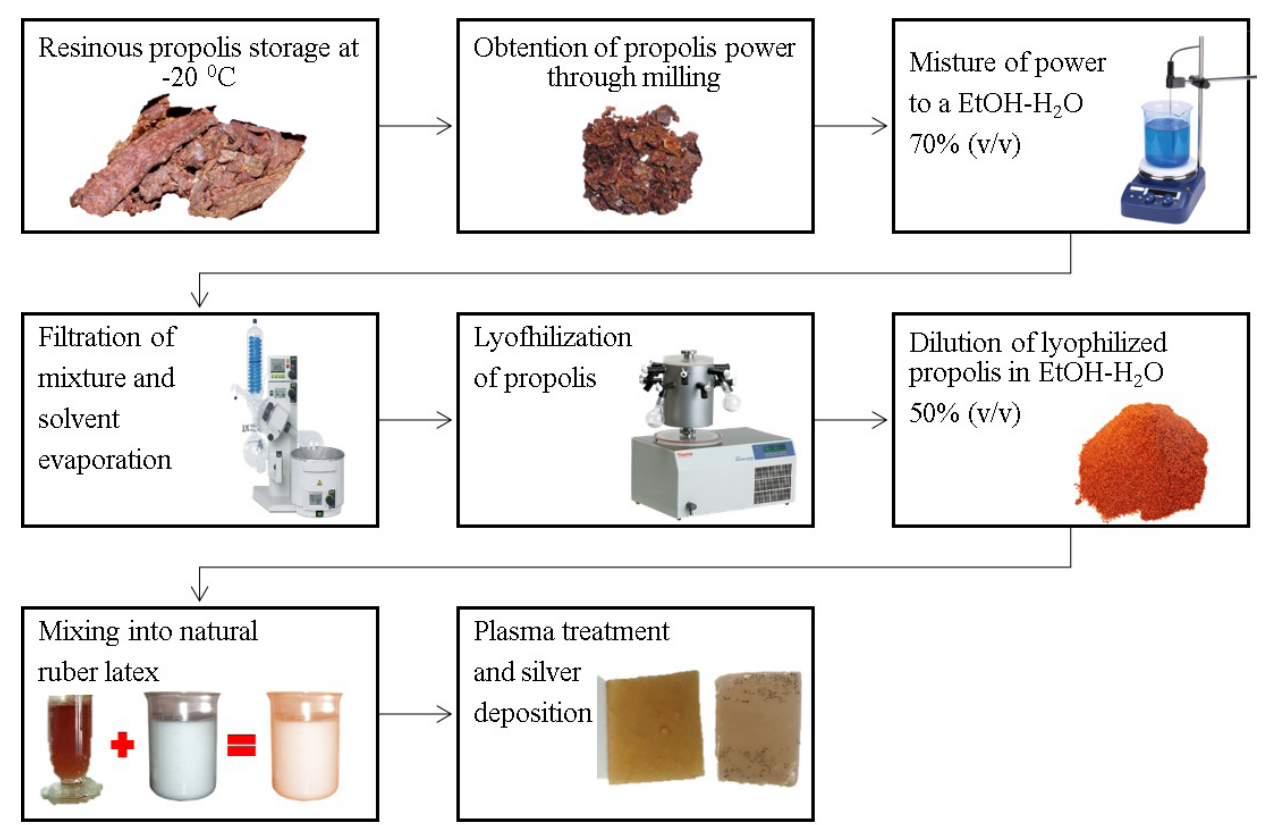

Figure 1. Flow chart for the methodology adopted in the preparation of NRL-RP films.

degradation on NRL. High frequency glow discharges, operating at $13.56 \mathrm{MHz}$ and low pressures $(\leq 100 \mathrm{~Pa})$, are usually adequate for general polymeric films due to excellent uniformity (i.e., plasma permeation) in the treatment and absence of hot arcs, which may harm the material ${ }^{39}$. The films produced in this process were NRLPla and NRL-RP-Pla.

\subsection{Silver deposition}

Silver deposition on the NRL and NRL-RP films was carried out by magnetron sputtering technique. A solid silver target (99.9\% purity) distanced $6.0 \mathrm{~cm}$ from samples was used. The base pressure was of $3.0 \times 10^{-7} \mathrm{mbar}$ and argon (Linde, Brazil, 99.9992\%) plasma was ignited. NRL films containing silver (NRL-Ag) and silver + RP (NRL-RP-Ag) were produced. The optimized parameters used in the silver deposition were shown in Table 1.

To form nanoparticles instead of a continuous film, the time and power of the process was set as low. In addition, the treatment took place at room temperature, so that the silver does not diffuse into the matrix and has difficulty in being leached.

Table 1. Experimental parameters used for silver deposition on NRL films.

\begin{tabular}{cc}
\hline Experimental parameter & Value \\
\hline Work pressure & $2.0 \times 10^{-3} \mathrm{mbar}$ \\
\hline DC power & $20 \mathrm{~W}$ \\
\hline Argon flow & $5.0 \mathrm{~cm}^{3} / \mathrm{min}$ \\
\hline Temperature & $25^{\circ} \mathrm{C}$ \\
\hline Deposition time & $3.0 \mathrm{~s}$ \\
\hline
\end{tabular}

\subsection{Physico-chemical characterization}

\subsubsection{Attenuated total reflectance Fourier transform infrared spectroscopy (ATR-FTIR)}

The physico-chemical characterization of the NRL and NRL-RP films was carried out by analyzing their functional groups through ATR-FTIR using a spectrophotometer equipment (model 400, Perkin-Elmer, USA). The spectra were registered in transmittance mode using an interval of wavelengths between 4000 and $500 \mathrm{~cm}^{-1}$.

\subsubsection{Elemental quantitative analysis (RBS)}

Elemental quantitative analysis was done by Rutherford backscattering spectrometry (RBS). A 3.0 MV Tandem ion accelerator with a monoenergetic ion beam of $\mathrm{He}^{+}$of 2.0 MeV and backscattering detection angle of $165^{\circ}$ was used. Through this analysis, it was possible to obtain the concentration of deposited silver on the produced NRLAg films.

\subsubsection{Water contact angle (WCA)}

Through sessile drop technique, it was possible to measure the contact angle to determine the wettability of the films (NRL, NRL-Ag, NRL-RP, NRL-RP-Ag, NRL-Pla) in a goniometer (model 300, SEO Phoenix, South Korea).

Three drops were tensioned with distilled water, each with 10 measurements at room temperature. Shelf life was estimated along a period of 5 months to evaluate the maintenance of obtained wettability as function of time. The samples were stored at room temperature/light inside a Petri dish to avoid humidity.

\subsection{Biological assays}

Assays were performed on all the samples (NRL, NRLAg, NRL-RP, NRL-RP-Ag, NRL-Pla and NRL-RP-Pla). 


\subsubsection{Evaluation of the efficiency of the plasma sterilization process}

The evaluation of the effectiveness of the plasma sterilization process was performed by submerging samples in the thioglycolate broth (Biomérieux, St, Lombard, USA) medium during 14 days. After this period, the appearance of turbidity in the thioglycolate medium was observed in case of contamination. Thus, the samples that showed no turbidity of the medium were classified as effectively sterilized.

\subsubsection{Isolation of adipose tissue-derived stem cells}

This study was approved by the Committee of Ethics in Research of the University of Caxias do Sul (Rio Grande do Sul State, Brazil) under the number 1.230.848 and is found in the system Comitê de Ética em Pesquisa/Comissão Nacional de Ética em Pesquisa (CEP/CONEP), Plataforma Brasil, on a national and unified basis of registers for research involving human beings, belonging to the Ministry of Health under the protocol CAAE: 46199015.2.0000.534. The cell isolation was based on the protocol described by Zuk et al. ${ }^{40}$, with some modifications.

In the $\mathrm{ZuK}$ protocol, colagenase I is used. In our isolation of stem cells from adipose tissue, colagenase II was used. The adipose tissue was consecutively washed with $1 \times$ PBS and submitted to the enzymatic process of complete tissue digestion with $1.0 \mathrm{mg} / \mathrm{mL}$ of collagenase II (Sigma Aldrich, St. Louis, Missouri, USA) in $1 \times$ PBS for $30 \mathrm{~min}$ in a water bath, with shaking every $5 \mathrm{~min}$. After, the adipose tissue was centrifuged for $10 \mathrm{~min}$ at $1400 \mathrm{rpm}$, the supernatant was removed and stromal vascular fraction (SVF) was isolated. Dulbecco's modified eagle medium (DMEM) supplemented with $10 \%$ of fetal bovine serum (FBS) and $1 \%$ of penicillin/streptomycin $(\mathrm{P} / \mathrm{S})$ was added to the inactivation of the enzymatic digestion process and centrifugation was performed at $1000 \mathrm{rpm}$ for $10 \mathrm{~min}$. The pellet was resuspended in DMEM/F12 supplemented and seeded in culture bottle and kept in a humidified incubator at $37^{\circ} \mathrm{C}$ with $5 \%$ of $\mathrm{CO}_{2}$.

In addition, stem cells were characterized by the methodology described by Dominic et al. ${ }^{41}$, with modifications; the cell differentiation in vitro for bone, cartilage and adipose tissue was proceeded using a cell differentiation proper medium.

\subsubsection{Cytotoxicity assays}

The cytotoxicity assays were carried out using both mouse fibroblasts L929 cells and ADSCs. To determine the cytotoxicity and the biocompatibility of the films, standardized methods were applied according to ISO $10993-05^{42}$ and ISO $10993-12^{43}$. To obtain an extract solute to be used upon cells in 3-(4,5-dimethylthiazol-2-yl)-2,5-diphenyltetrazolium bromide (MTT) assay, the DMEM culture medium supplemented with $10 \%$ of FBS and $1 \%$ of $\mathrm{P} / \mathrm{S}$ was put into contact with the samples at a $0.1 \mathrm{~g} / \mathrm{mL}$ concentration during $24 \mathrm{~h}$ at $37{ }^{\circ} \mathrm{C}$ in $5 \%$ of $\mathrm{CO}_{2}$

\subsubsection{Indirect MTT cytotoxic assays}

Cytotoxicity was evaluated by indirect MTT assays. This method is based on the reduction of MTT to formazan crystals by mitochondrial dehydrogenases ${ }^{44}$. L929 and ADSCs were seeded at a density of $5.0 \times 10^{4}$ cells $/ \mathrm{mL}$ in $100 \mu \mathrm{L}$ of DMEM culture medium supplemented with $10 \%$ of $\mathrm{FBS}$ and $1 \%$ of $\mathrm{P} / \mathrm{S}$. After obtaining a confluence of $70-80 \%$, cells were treated with the extract solution obtained as previously reported from the immersion of the samples in culture medium for 1,2 and 7 days at $37^{\circ} \mathrm{C}$ and $5 \%$ of $\mathrm{CO}_{2}$. For negative control, a DMEM medium (10\% of FBS and $1 \%$ of $\mathrm{P} / \mathrm{S}$ ) was used and for positive control, $5 \%$ of dimethylsulfoxide (DMSO). The medium was removed and $1.0 \mathrm{mg} / \mathrm{mL}$ of MTT in a medium free from FBS and $\mathrm{P} / \mathrm{S}$ was added to the wells of microplates. The plates were incubated at $37{ }^{\circ} \mathrm{C}$ during $2 \mathrm{~h}$ in a humidified atmosphere with $5 \%$ of $\mathrm{CO}_{2}$. Subsequently, MTT solution was removed and formazan crystals were dissolved in $100 \mu \mathrm{L}$ of DMSO. Spectrophotometric reading at $570 \mathrm{~nm}$ was carried out using a microplate reader (Max 190 Spectra, Molecular Devices, USA) and results were expressed as percentage of cell viability. Absorbance of negative control represented $100 \%$ viability and values of treated cells were calculated as a percentage of control.

Statistical significance was evaluated through t-test and One-way analysis of variance (ANOVA) with the singlestep multiple comparison procedure (Tukey) to evaluate the statistical differences in case of normal distribution. In this work, we used six different samples and three different times, so the purpose of applying ANOVA was to perform the statistical test to check if there is a difference in the distribution of a measure between the groups. Significance was accepted for p-value inferior to 0.05, using Statistical Package for the Social Sciences (SPSS, version 19.0) for Windows.

\subsubsection{Agar overlay assay}

Cytotoxicity was evaluated by the indirect method of the neutral red dye assay with transformation of lysosomes from viable cells ${ }^{45}$. L929 and ADSCs were seeded into 6-well plates at a density of $1.0 \times 10^{5}$ cells per well in a DMEM culture medium supplemented with $10 \%$ of FBS and $1 \%$ of $\mathrm{P} / \mathrm{S}$. After $24 \mathrm{~h}$, the culture medium was removed and $1.0 \mathrm{~mL}$ of the covering medium was added to each well. The covering medium was composed by $1.8 \%$ of agar with neutral red dye at $0.01 \%$ and concentrated MEM $2 \mathrm{X}$, in equal amounts.

Then, the sterilized samples were put at the center of each well in an incubator at $37^{\circ} \mathrm{C}$, with $5 \%$ of $\mathrm{CO}_{2}$ for $24 \mathrm{~h}$. The samples were evaluated macro and microscopically (Table 2) by observing halo formation around the samples, which is correlated to their cytotoxic features.

\subsubsection{Determination of topographical distribution and morphological patterns of L929 and ADSCS deposited on the films}

For determining properties such as adhesion, topographical distribution and morphology, L929 and ADSCs were seeded into 6 -well plates at a density of $5.0 \times 10^{4}$ cells $/ \mathrm{mL}$ during 1 , 2 , and 7 days. Exactly $2000 \mu \mathrm{L}$ of DMEM culture medium supplemented with $10 \%$ of FBS and $1 \%$ of $\mathrm{P} / \mathrm{S}$ was used over the samples for 1, 2 and 7 days. Following this, cells were fixed with 3\% glutaraldehyde solution in PBS (v/v) for $15 \mathrm{~min}$ and dehydrated with increase ethanol grade 30,50 , 70,90 and $100 \%$ (v/v) during $10 \mathrm{~min}$ for each concentration. The samples were kept inside a desiccator until analysis. A 
Table 2. Reactivity classification for agar diffusion test according to ISO10993- $5^{42}$ protocol.

\begin{tabular}{ccl}
\hline Grade & Cytotoxicity & \multicolumn{1}{c}{ Toxicity zone } \\
\hline 0 & None & Absence of inhibition over the sample \\
\hline 1 & Slight & Malformation under the sample \\
\hline 2 & Mild & Inhibition zone limited to the area below sample \\
\hline 3 & Moderate & Inhibition zone from sample that reaches $1.0 \mathrm{~cm}$ \\
\hline 4 & Severe & Inhibition zone that extends beyond $1.0 \mathrm{~cm}$ from the sample \\
\hline
\end{tabular}

field emission gun equipped scanning electron microscope (FEG-SEM) (Mira 3, Tescan, Czech Republic) was used in these assessments. The images were made in the treated side of the samples. The working distance was between 15 and $20 \mathrm{~mm}$ and the accelerating voltage was either 10 or $15 \mathrm{kV}$.

\subsubsection{Elemental analysis through energy dispersive spectroscopy (EDS)}

The elemental analysis of the films was obtained through a microscope (Mira Tescan 3), equipped with an energy dispersive spectrometer (EDS) of the silicon drift detector (SDD) type. The images were obtained from the treated side of the samples. The working distance was between 15 and $20 \mathrm{~mm}$ and the accelerating voltage was $15 \mathrm{kV}$.

\section{Results and Discussion}

\subsection{Attenuated total reflectance Fourier transform infrared spectroscopy (ATR-FTIR)}

Figure 2 shows the ATR-FTIR spectra for NRL and NRL-RP films. As can be observed, both spectra are very similar, as already seen on the literature ${ }^{46}$. This is an indicative that the functional groups on NRL and RP are almost the same. New bands were not seen on the NRL-RP spectrum in comparison with the NRL spectrum, so no chemical interaction between latex and red propolis took place. Physical interaction between NRL and RP, by other hand, is desired, once it allows the gradual and easier release of RP compounds into the wound environment ${ }^{47}$. In order to study the functional groups present in the NRL matrix, which will be the same for all films produced and, therefore, has great importance for this study, the wavelengths related to its compounds were analyzed. The attribution of the main bands related to ATR-FTIR spectrum of NRL is listed in Table 3. Absorption bands for the characteristic vibrational modes of cis-1,4-polyisoprene are highlighted in bold.

Because they have carbonyl groups (aldehydes, esters, carboxylic acids, amides and ketones), the region between 1800 and $600 \mathrm{~cm}^{-1}$ is of greatest interest. These functional groups are mostly related to latex proteins, which are associated to possible regenerative process. It is noted that there is no indication of sulfur presence, which is used in latex during manufacturing for stabilization ${ }^{38}$. This fact indicates that the amount of this element is relatively low, which favors biomedical use.

Adsorption bands that characterize RP are mostly present in 1646, 1451, 1249 and $1043 \mathrm{~cm}^{-1}$, concurring with literature reports ${ }^{50,51}$. These bands are originated from the presence of aromatic rings and flavonoids, which are the main responsible agents in bactericidal and antioxidant properties of propolis ${ }^{52}$.
Table 3. Absorption bands attribution for each found wavelength ${ }^{38,48,49}$ in NRL ATR-FTIR spectrum.

\begin{tabular}{cl}
\hline $\begin{array}{c}\text { Wavelength } \\
\left(\mathrm{cm}^{-1}\right)\end{array}$ & \multicolumn{1}{c}{ Attribution } \\
\hline $\mathbf{3 2 8 7}$ & $\begin{array}{l}v_{\mathrm{s}} \mathrm{O}-\mathrm{H} \text { and } v_{\mathrm{s}} \mathrm{N}-\mathrm{H} \text { (humidity and hydrogen binding } \\
\text { in proteins })\end{array}$ \\
\hline $\mathbf{3 0 3 6}$ & $v_{\mathrm{s}}(=\mathrm{C}-\mathrm{H})$ \\
\hline $\mathbf{2 9 5 9}$ & $v_{\mathrm{s}} \mathrm{C}-\mathrm{H}$ in $\mathrm{CH}_{3}$ \\
\hline $\mathbf{2 9 1 3}$ & $v_{\mathrm{s}} \mathrm{C}-\mathrm{H}$ in $\mathrm{CH}_{3}$ \\
\hline $\mathbf{2 8 4 9}$ & $v_{\mathrm{s}} \mathrm{C}-\mathrm{H}$ in $\mathrm{CH}_{2}-$ \\
\hline $\mathbf{2 7 2 1}$ & $v-\mathrm{CH}_{2}-\mathrm{C}=\left(\mathrm{CH}_{3}\right)$ \\
\hline 1644 & Primary amide $v \mathrm{C}=\mathrm{O}$ in $\mathrm{H}$ binding with water \\
\hline 1556 & $v_{\mathrm{s}} \mathrm{C}=\mathrm{O}$ of $\mathrm{C}-\mathrm{OO}-$ in proteins \\
\hline $\mathbf{1 4 4 4}$ & $\delta-\mathrm{CH}_{2}-$ \\
\hline $\mathbf{1 3 7 7}$ & $\delta_{\mathrm{s}}-\mathrm{CH}_{3}$ \\
\hline $\mathbf{1 3 0 2}$ & $-\mathrm{CH}_{2}-$ twist \\
\hline $\mathbf{1 2 3 8}$ & $-\mathrm{CH}_{2}-$ twist \\
\hline $\mathbf{1 1 2 2}$ & $\mathrm{C}-\mathrm{H}$ bending in plane or $\mathrm{v}(\mathrm{C}-\mathrm{C})$ cis or $\mathrm{CH}_{2}$ wag \\
\hline 1071 & $v \mathrm{C}-\mathrm{O}$ in aliphatic ether or $\mathrm{C}-\mathrm{O}$ in ether \\
\hline $\mathbf{8 3 2}$ & $\delta \mathrm{C}=\mathrm{C}-\mathrm{H}$ \\
\hline 742 & $\rho-\mathrm{CH}_{2}-$ \\
\hline 567 & $\beta \mathrm{C}-\mathrm{C}-\mathrm{C}$ \\
\hline
\end{tabular}

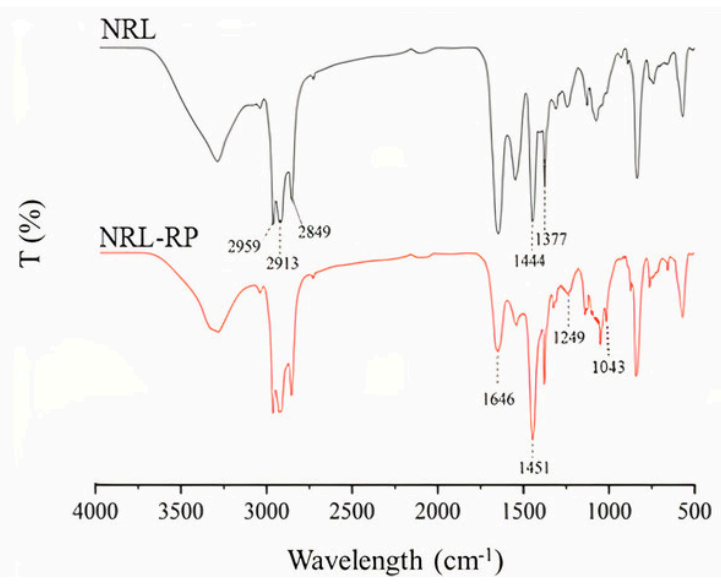

Figure 2. ATR-FTIR spectra of NRL and NRL-RP.

\subsection{Elemental quantitative analysis (RBS)}

RBS analysis on NRL-Ag film gave an overall insight on elemental composition. The obtained spectrum shows a peak that refers to carbon (mostly present in cis-1,4-polyisoprene), besides nitrogen and oxygen, which are related to proteins and humidity (Figure 3). This is in full consonance with ATR-FTIR spectrum, previously displayed. 
Table 4. Contact angle measurements for NRL, NRL-Pla, NRL-Ag, NRL-RP and NRL-RP-Ag films.

\begin{tabular}{ccccc}
\hline & \multicolumn{4}{c}{ Contact angle } \\
\hline NRL & NRL-Pla & NRL-Ag & NRL-RP & NRL-RP-Ag \\
\hline & & & \\
\hline
\end{tabular}

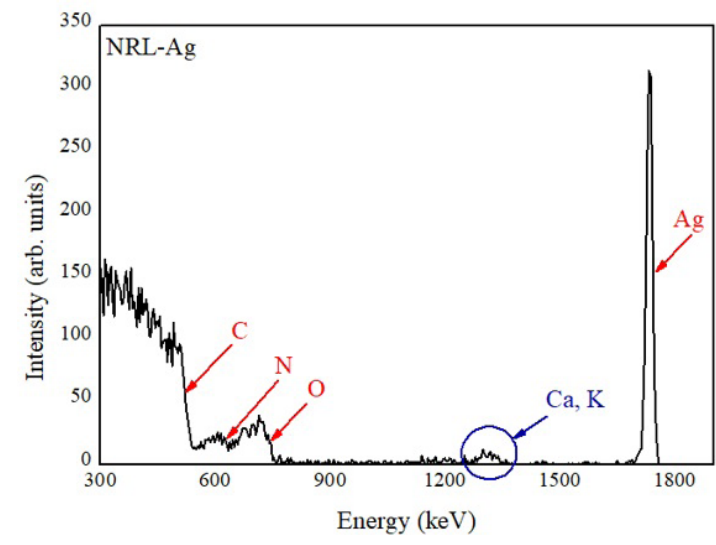

Figure 3. RBS spectrum of NRL-Ag film.

Moreover, a narrow and intense peak attributed to silver was observed, indicating that this element is present at the film surface ${ }^{53}$. This appearance is also an indication that silver is in the nanoparticulate form, not forming a film, where the peak would appear as a plateau, as shown in the literature ${ }^{54,55}$. The areal amount of deposited silver calculated through the spectrum was $1.6 \times 10^{16}$ atoms $/ \mathrm{cm}^{2}$ or $2.87 \mu \mathrm{g} / \mathrm{cm}^{2}$. The literature supports that different products consisting in wound dressings can contain silver nanoparticles concentrations between $1.0 \mu \mathrm{g} / \mathrm{cm}^{2}$ and $1.34 \mathrm{mg} / \mathrm{cm}^{2}$. This way, the silver concentration found in this work would fit into the lower limit within the range of these traditional products, reducing the risk of cytotoxicity to human cells ${ }^{56-58}$. It is important that AgNPs are found in the material's surface, because their release must occur in the first hours after application of the wound dressing, which is a critical moment to achieve bactericidal activity.

Another peak circled in blue (around $1300 \mathrm{keV}$ ) could be related to elements such as calcium and potassium, both of which are absorbed by the soil, taking part in the biosynthesis of natural latex ${ }^{59}$.

\subsection{Water contact angle (WCA)}

The contact angle measurements for NRL, NRL-Pla, NRL-Ag, NRL-RP and NRL-RP-Ag films are represented in Table 4.

The results found for sessile drop technique measurements showed that NRL film present a contact angle of nearly hydrophobic behavior. After plasma treatment (NRL-Pla), as new functional groups were formed (carbonyl, carboxyl and hydroxyl groups) ${ }^{60}$, a hydrophilic character was evinced.
Silver-containing films (NRL-Ag and NRL-RP-Ag) also provided a decrease in the contact angle, falling in hydrophilic range as expected, once incorporation of AgNPs is responsible for rising the wettability in a matrix, besides providing the bactericidal effect ${ }^{61}$. RP, hydrophilic itself, is also an enhancer of wettability when incorporated ${ }^{50}$.

This result indicates that NRL-Ag, NRL-RP, NRL-RP$\mathrm{Ag}$ and NRL-Pla films could be used as dressings, since hydrophilicity is correlated with improvement in both scarring and tissue regeneration ${ }^{62}$.

Furthermore, it is important to assess shelf life, in terms of wettability of the samples, as it will dictate for how long they retain a favorable condition for biomedical application, i.e., the maintenance of their hydrophilicity. There is a tendency in contact angle increasing as function of time. This happens due to the aging effect, which depends on the temperature, polymer type and storage humidity. Opposed to polymers predominantly crystalline, which have a more rigid structure and have a lower aging rate, amorphous polymers have greater mobility in their polymeric chains and are more likely to aging effect. After some time of storage, hydrophilicity of the plasma treated films is reduced due to the reorientation of functional groups formed on the surface toward bulk material and the diffusion of these groups on the polymeric matrix ${ }^{63,64}$.

The samples containing silver also present a decrease in the contact angle. This phenomenon is expected because the AgNPs tend to form aggregates, promoting roughness effects ${ }^{65,66}$ that affect the wettability. To investigate this effect, contact angles were measured throughout five months. The results are found in Table 5.

This assessment highlights the period that the samples will retain their hydrophilic character for 4 to 5 months. NRL-RPAg samples should be preferably used by the end of the final month after their manufacturing. On the other hand, NRL-RP did not present significant changes in contact angle along the evaluated time, indicating it could be used over a longer period.

\subsection{Evaluation of the efficiency of the plasma sterilization process}

Although simple, the thioglycolate broth test can serve as a support for the sterility control of several materials ${ }^{45}$. As already explained, to evaluate the effectiveness of the sterilization process of plasma treatment and silver deposition by magnetron sputtering in a vacuum chamber, the films were immersed in medium of thioglycolate broth for 14 days. After this period, the appearance or not of turbidity in the thioglycolate broth 
Table 5. Results of contact angle for modified samples.

\begin{tabular}{cccccc}
\hline Sample/month & 1 & 2 & 3 & 4 & 5 \\
\hline NRL-Pla & $25 \pm 1^{\circ}$ & $36 \pm 1^{\circ}$ & $45 \pm 1^{\circ}$ & $65 \pm 1^{\circ}$ & $80 \pm 1^{\circ}$ \\
\hline NRL-Ag & $50 \pm 1^{\circ}$ & $52 \pm 1^{\circ}$ & $56 \pm 1^{\circ}$ & $64 \pm 1^{\circ}$ & $79 \pm 1^{\circ}$ \\
\hline NRL-RP & $40 \pm 1^{\circ}$ & $42 \pm 1^{\circ}$ & $44 \pm 1^{\circ}$ & $44 \pm 1^{\circ}$ & $44 \pm 1^{\circ}$ \\
\hline NRL-RP-Ag & $75 \pm 1^{\circ}$ & $83 \pm 1^{\circ}$ & $83 \pm 1^{\circ}$ & $83 \pm 1^{\circ}$ & $83 \pm 1^{\circ}$ \\
\hline
\end{tabular}

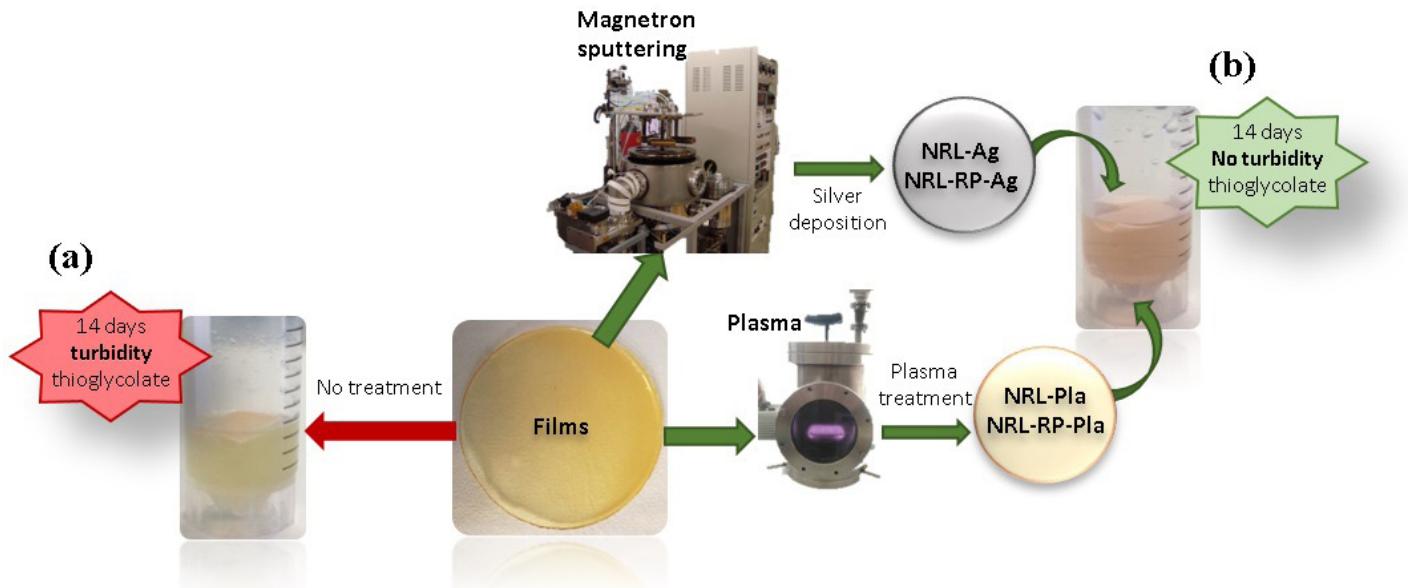

Figure 4. Scheme of the plasma sterilization process: (a) vial showing turbidity; (b) vial absent of turbidity films treated with plasma or silver coverage.

was evaluated. In the NRL films with no plasma treatment or silver deposition (NRL and NRL-RP), the medium was cloudy (Figure 4a), evidencing bacterial contamination. In this case, the samples would require a further sterilization process, such as ethylene oxide. Plasma treatment or silver deposition, on the other hand, were effective to eliminate microorganisms (Figure 4b), where no turbidity of the broth was seen (NRLPla, NRL-RP-Pla, NRL-Ag and NRL-RP-Ag).

Many of the usual sterilization processes may cause modifications in the films chemical structure, interfering directly in their properties ${ }^{33}$. High temperature, as seen in autoclave, may degrade the biomaterial, while the ethylene oxide alters surface chemistry, allowing the formation of toxic residues and undesirable byproducts ${ }^{67}$.

Due to their flexibility regarding material size and shape, plasma-based treatments are gaining more visibility. Cold plasma method is efficient in sterilizing biomedical devices and offers several advantages, one of them is a clean process happening in a wide range of temperatures, including room temperature $^{68}$. The biocide effect is possible due to the formation of reactive species that attack nucleophilic sites in the microorganisms, inactivating them ${ }^{69}$. Therefore, the treatments applied on the films can be effective as a sterilization process, minimizing costs and time in industrial processes.

\subsection{Cell culture assays}

\subsubsection{Isolation of adipose tissue-derived stem cells}

The adipose tissue was obtained from a liposuction procedure and submitted to enzymatic digestion for the purpose of isolating stem cells. After 4 days, the cultures were monitored in an inverted microscope, through which a great amount of adhered cells in expansion were observed, corroborating the findings of Dominic et al. ${ }^{41}$, showing an adhesion to plastic and expansion when in culture.

In addition, characterization through flow cytometry analysis, which garnered evidence that ADSCs exhibited little or no expression for all hematopoietic cells markers were performed ${ }^{70}$. It is also expected that cells do not express in vitro markers that have the ability to differentiate into osteoblasts, adipocytes and chondroblasts ${ }^{41,71}$, a fact also evidenced in the analysis (Table 6). Mesenchymal stem cells derived from adipose tissue were also assessed regarding its differentiation capacity in various types of mesenchymal lineages ${ }^{72,73}$. All induced ADSCs samples presented the ability to differentiate into osteogenic, adipogenic and chondrogenic tissues.

ADSCs are a source of mesenchymal stromal cells and, when used in grafting, have released factors that stimulate angiogenesis, accelerating the wound healing process ${ }^{74}$. Lotfi et al. ${ }^{75}$ showed that autologous ADSCs transplantation, increases vessel density, type I collagen and growth factor secretion, healing the wound. The application of ADSCs associated to biocompatible materials has shown favorable results in injured places, being suggested as a possible therapy for the treatment of skin wounds ${ }^{76}$.

\subsubsection{Indirect MTT cytotoxic assays}

To evaluate the cytotoxic effect of the films, an extract was initially prepared referring to each condition according to the described methodology of standards ISO 10933-5 $5^{42}$ and ISO $10993-12^{43}$, and these were put into contact with 
(a)

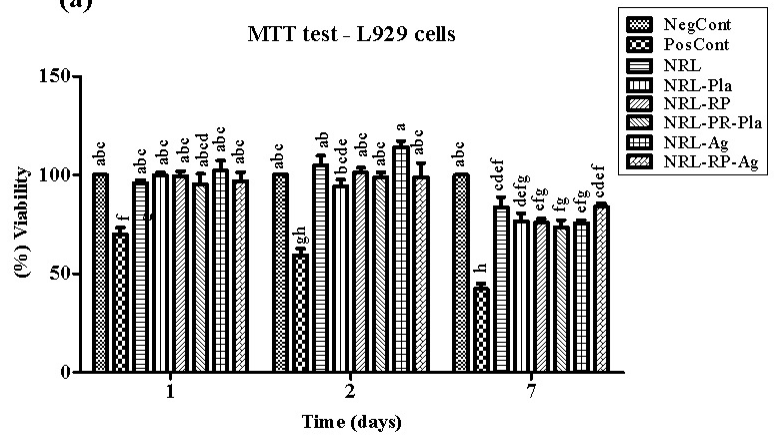

(b)

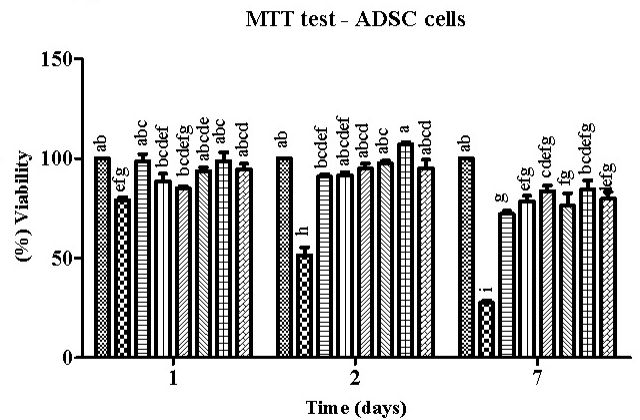

Figure 5. Cytotoxic effect obtained by the MTT indirect test according to ISO 10993-5-200942 and ISO 10993-12-200443 of the extracts compared to the negative (DMEM medium, $10 \%$ of FBS and $1 \%$ of P/S) and positive control (DMEM medium, $10 \%$ of SFB, $1 \%$ of P/S and 5\% of DMSO) on the viability of (a) L929 and ADSCs (b), treated for 1, 2 and 7 days. NegCont: negative control; PosCont: positive control; NRL, NRL-Pla, NRL-RP, NRL-RP-Pla, NRL-Ag, NRL-RP-Ag films. * Letters (a, b, c, d, e, f, g, h and i) correspond to the statistically significant differences using the ANOVA-Tukey test $(\mathrm{p} \leq 0.05)$.

Table 6. Cell surface markers observed through flow cytometry analysis used for the identification of stem cells derived from adipose tissue and its percentage.

\begin{tabular}{cc}
\hline Cell surface markers & Result (\%) \\
\hline \multicolumn{3}{c}{} \\
\hline CD29 & Positive \\
\hline CD44 & $98.7 \pm 1.06$ \\
\hline CD73 & $98.3 \pm 2.65$ \\
\hline CD90 & $98.7 \pm 1.39$ \\
\hline CD105 & $97.1 \pm 2.17$ \\
\hline CD14 \\
\hline CD34 & $0.4 \pm 0.61$ \\
\hline CD45 & $0.1 \pm 0.12$ \\
\hline CD184 & $0.1 \pm 0.06$ \\
\hline HLA-DR & $0.1 \pm 0.10$ \\
\hline STRO1 & $0.5 \pm 0.87$ \\
\hline
\end{tabular}

L929 cell line recommended by international standards and ADSCs. MTT assay results are represented in Figure 5.

According to ISO $10993-5^{42}$, a material triggers cytotoxic effects when a reduction in cell viability is shown to be superior to $30 \%$ after $24 \mathrm{~h}$ of exposition. Comparing cell viability for these films with the international standards classification for medical devices, the assays revealed that none of the samples present cytotoxic effect for L929 and ADSCs (Figure 5a and 5b).

After 1 and 2 days of incubation, it was verified that the viability of the extracts was superior in comparison to 1 day $(69.79 \%)$ and 2 days $(59.29 \%)$ positive control for L929 cells, and 1 day (79.08\%) and 2 days (51.49\%) for ADSCs, showing statistical differences related to exposure time in both cells. Our findings concur well with the findings of Watthanaphanit and Rujiravanit ${ }^{77}$ in cell viability assay with L929 cells, which demonstrated that the percentage of cell viability for all samples and all concentrations of the extract with NRL was higher than $70 \%$, thus ensuring its applicability accordingly to safety standards.

Another aspect than can be emphasized in the cell cytotoxicity assay is the assessment taking into account the exposure time of L929 and ADSCs for 7 days; a greater reduction in viability was observed for films: (1) NRL (83.58\% and $72.21 \%$ ); (2) NRL-Pla (76.34\% and $78.58 \%$ ); (3) NRL-RP (75.77\% and $83.72 \%$ ); (4) NRL-Ag (75.51\% and $84.50 \%$ ); (5) NRL-RP-Ag ( $83.87 \%$ and $79.84 \%)$. On the seventh day, for both L929 and ADSC cells, we were able to observe a static similarity; however, according to the indirect cytotoxicity assay, no statistical difference was observed between the treatments using primary and cell lineage culture.

Films not showing cytotoxic effect even after a week of exposition in the MTT assay, according to ISO 10993- $5^{35}$, with viability superior to positive control $(42.26 \%$ and $27.61 \%$ ). According to Pichayakorn et al. ${ }^{78}$, studying NRL with peel-off masks, it was observed that they can be applied to pharmaceutical products and cosmetic formulations, as they do not present toxic effect and irritability when used in humans. Zancanela et al. ${ }^{47}$ showed that NRL films with incorporation of RP presented antifungal activity against Candida albicans and potentially act on wound healing process. In another in vitro study, the author adds that the incorporation of RP into NRL films did not demonstrate cytotoxic activity in rat fibroblast cells (3T3), by the contrary, it maintained its mechanical characteristics and could act as a physical barrier against the penetration of infectious agents ${ }^{46}$.

For silver containing membranes (NRL-Ag and NRL-RP-Ag), the cell viability was above the minimum threshold of $70 \%$, indicating no toxic behavior. The amount of silver for the produced membranes (previously discussed in the elemental quantitative analysis section) 
is not sufficient to generate toxic effects on the cell lines, especially once they are on the low range of silver concentration for wound dressing applications.

Thus, it was observed that standard L929 cells did not differ from the ASDC isolated in this study. The prospects of performing autologous ADSCs grafts in burns associated with the topical use of a potent antimicrobial, anti-inflammatory and regenerating agent based on RP extracts ${ }^{79}$ could be advantageous with occlusive dressings with natural latex rubber ${ }^{46,80}$.

\subsubsection{Agar overlay assay}

Neutral red dye has been used as an indicator of qualitative cytotoxicity in primary cultures and other cell lineages. It is characterized by accumulating lysosomes in the viable cells that incorporated this vital dye, slightly cationic $^{45}$. This reagent penetrates cell membrane by non-ionic passive diffusion and concentrate on cells lysosomes, where it fixates through electrostatic bonding to anionic groups, including hydrophobic phosphates of the lysosomal matrix ${ }^{81}$. This assay measures a direct contact and evaluates cytotoxicity simulating material in direct skin contact over a long period ${ }^{82}$.

No evidence of cytotoxic-related halo formation surrounding the films was observed. Conversely, a microscopic assay showed some cell alteration, such as damage to cell morphology and neutral red dye distaining, indicating possible cell lysis. Such findings were accentuated in L929 cell lineage. However, the findings for L929 and ADSCs were classified under moderate cytotoxicity to agar overlay assay, due to the fact that they presented a distain zone of $1.0 \mathrm{~cm}$ from the sample. It is worth to stress that although the ADSCs presented a smaller discoloration zone than that of L929, a decrease in cell intensity in red stain for viable cells was observed in comparison to its counterpart positive control (Figures 6 and 7).

\subsubsection{Determination of adhesion, topographical distribution and morphological patterns of L929 and ADSCs deposited on the films}

Adhesion, topographical distribution and morphology of both L929 and ADSCs deposited over the aforementioned films were evaluated. It could be observed that while the first and second days showed similar cell proliferation, in the seventh day NRL-RP, NRL-Ag and NRL-RP-Ag presented a small increase over L929 cell adhesion and proliferation (Figures 8 and 9).

In addition, analogies between obtained results in the contact angle measurements were stated: a reduction in water contact angle is inversely proportional to cell adhesion and spreading over the material surface. Similar results were found by Tong et al. ${ }^{83}$, in which the behavior of 3T3 mouse fibroblast adhesion on diamond films and as a drawn conclusion, adhesion and proliferation for these cells is preferentially favored over hydrophilic surfaces, due to the favoring of protein adsorption, such as fibronectin and vitronectin that have a fundamental role in cell adhesion ${ }^{84}$.
For Liu et al. ${ }^{85}$, the wettability parameter is also one of the most important when it comes to cell response on materials. It is possible that the cells have a preference for hydrophilic surfaces. However, in ATR-FTIR analyses, functional groups with nonpolar characteristics were observed, thus the presence of nonpolar functional groups could plausibly explain the little cell adsorption and their morphological aspect, round-shaped and retracted cytoplasm, not expressing their fibroblastic characteristics.

The influence of roughness and porosity is equally important. In this study, surfaces of the films containing RP, treated with plasma and silver presented visually perceived rough surfaces and more hydrophilic surface, which may be favorable to cell adhesion ${ }^{86}$. The possibilities to modify the hydrophilic-hydrophobic characteristics make NRL a candidate for tissue engineering.

It should be mentioned, however, that cell adhesion is a complex process, affected by different factors, including particular cellular metabolism, surface properties of the host biomaterial and biological environment. Regarding a biomaterial, roughness, hydrophobicity, surface energy, chemical composition and porosity are crucial factors when expecting a certain cell response ${ }^{87}$.

\subsubsection{Elemental analysis through energy dispersive spectroscopy (EDS)}

Literature points out that NRL constitutes the cytoplasm of the lactiferous cells of the vegetal tissue on the tree cambium region $^{88}$. Nonetheless, the substances present in latex distribute themselves into three phases (mass/latex mass): (a) rubber particles (35\%): elastomer, phospholipids and polymerase enzymes; (b) aqueous phase (55\%): water, proteins and electrolytes; and (c) lutoid phase (10\%): proteins, lipids and carotenes ${ }^{89}$.

EDS analyses for NRL-RP film revealed the presence of the following elements: point (1) oxygen, gold and potassium; point (2) oxygen, gold, potassium, calcium and phosphor; and point (3) oxygen and gold (Figure 10a). In addition, NRL film showed the presence of the following chemical elements: point (4) calcium, oxygen and gold; point (5) calcium, oxygen, phosphor, potassium and sulphur; and point (6) calcium, oxygen and gold (Figure 10b). These results confirm several deposited particles, especially calcium, phosphorus and potassium, which are well-known functional materials for tissue regeneration ${ }^{90}$. Gold, on other hand, is frequently used for recovery of samples prior to the analysis on the microscope.

Therefore, d'Auzac ${ }^{91}$ also pointed that the aqueous medium of latex is charged with mineral salts, such as $\mathrm{K}^{+}$, $\mathrm{Na}^{+}, \mathrm{Mg}^{2+}$ e $\mathrm{Ca}^{2+}$. No nitrogenous groups resulted from the ammonia-based latex obtaining process were verified. This finding is important, once ammonia is known for its volatility and irritability for both respiratory tracts and skin pathways ${ }^{89}$. 


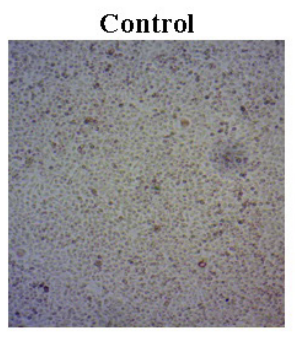

NRL

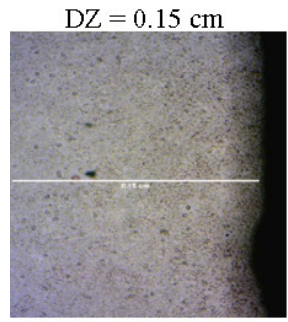

NRL-RP-Pla

$\mathrm{DZ}=0.15 \mathrm{~cm}$

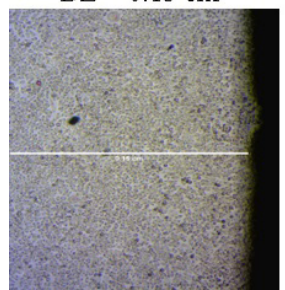

NRL-Pla

$\mathrm{DZ}=0.15 \mathrm{~cm}$

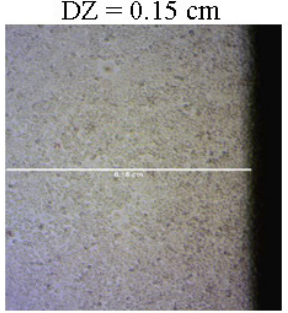

NRL-Ag

$\mathrm{DZ}=0.15 \mathrm{~cm}$

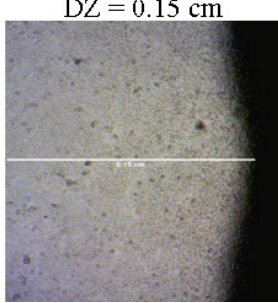

NRL-RP

$\mathrm{DZ}=0.15$

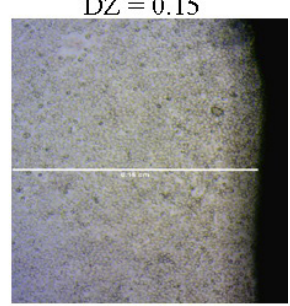

NRL-RP-Ag

$\mathrm{DZ}=0.15 \mathrm{~cm}$

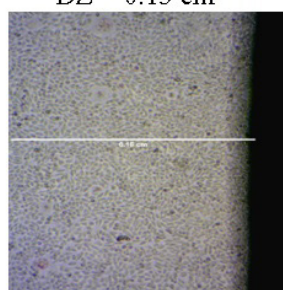

Figure 6. Overlay assay with L929 cells. Visualization on inverted microscope (magnification of $40 \times$ ). Measurements of discoloration zones (DZ) carried out on ImageJ, with scale calibration $(0.1 \mathrm{~cm})$.

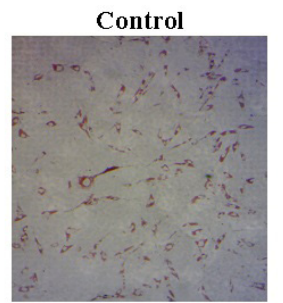

NRL-Pla

NRL

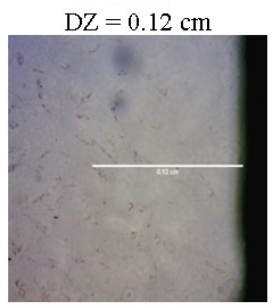

NRL-RP-Pla

$\mathrm{DZ}=0.1 \mathrm{~cm}$

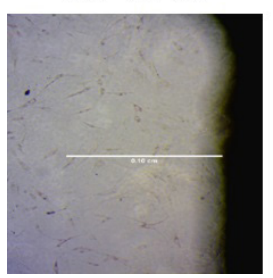

$\mathrm{DZ}=0.09 \mathrm{~cm}$

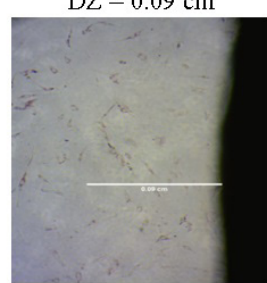

NRL-Ag

$\mathrm{DZ}=0.07 \mathrm{~cm}$

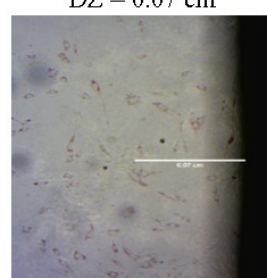

NRL-RP

$\mathrm{DZ}=0.1 \mathrm{~cm}$

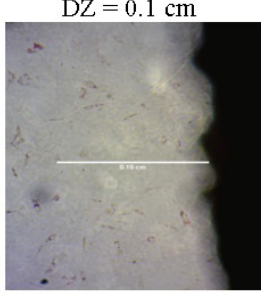

NRL-RP-Ag

$\mathrm{DZ}=0.08 \mathrm{~cm}$

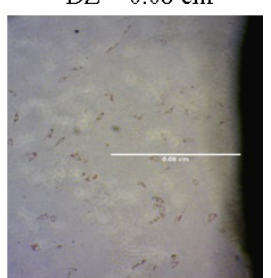

Figure 7. Overlay assay with ADSCs. Visualization on inverted microscope (magnification of $40 \times$ ). Measurements of discoloration zones (DZ) carried out on ImageJ, with scale calibration $(0.1 \mathrm{~cm})$. 


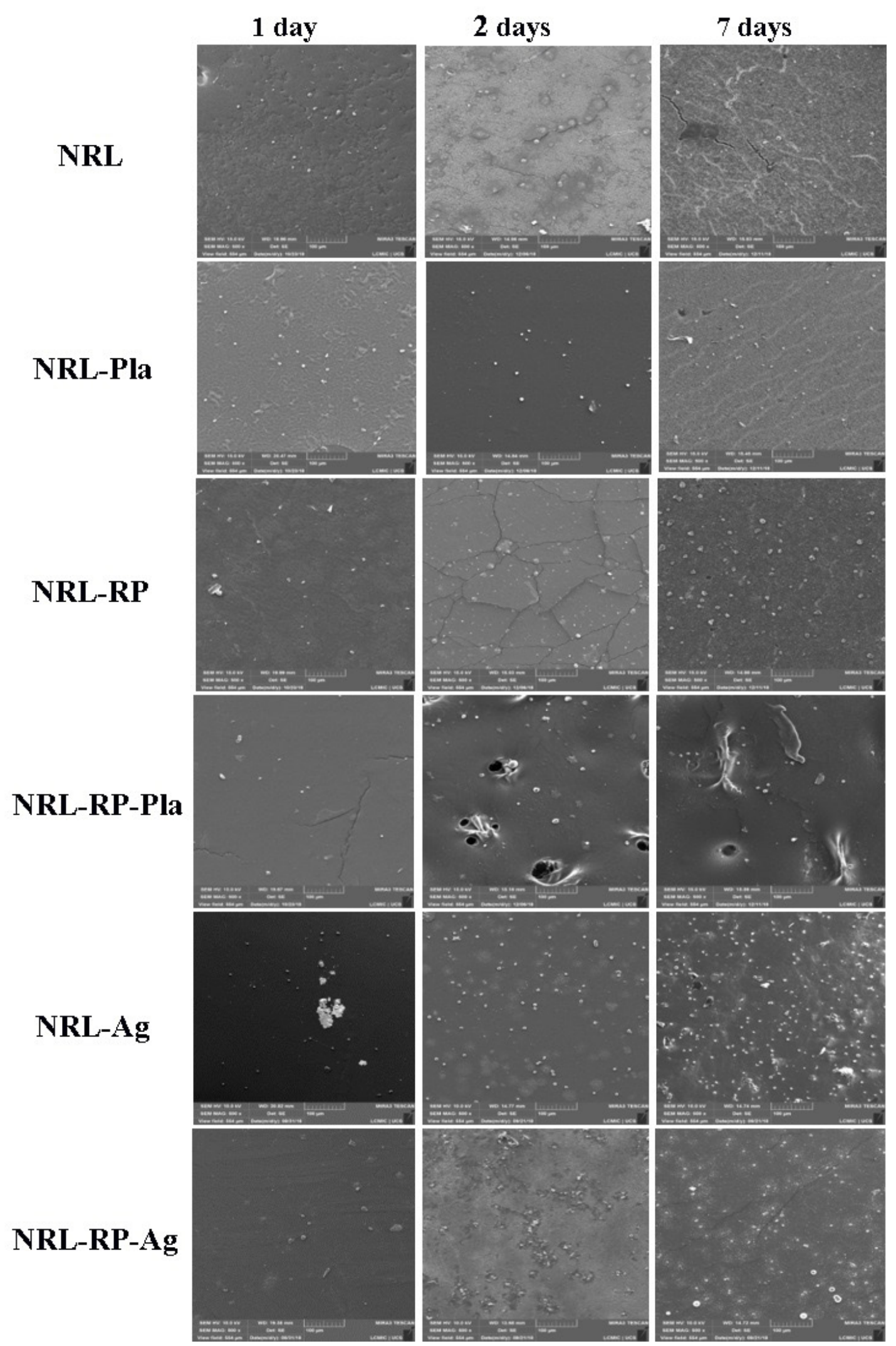

Figure 8. FEG-SEM micrographs $(500 \times)$. NRL; NRL-Pla; NRL-RP; NRL-RP-Pla; NRL-Ag; NRL-RP-Ag after 1, 2 and 7 days of L929 cellular incubation. 


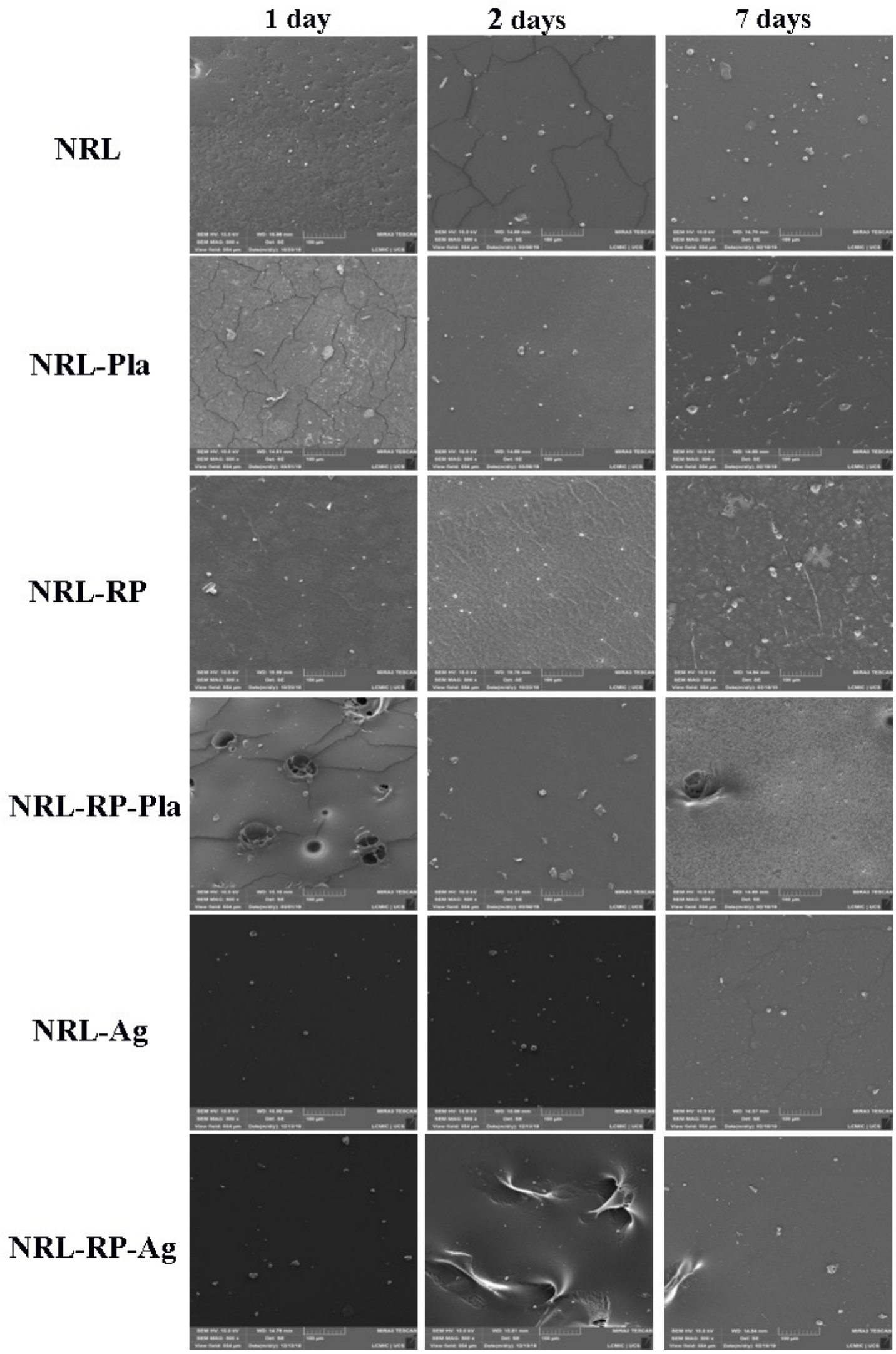

Figure 9. FEG-SEM micrographs $(500 \times)$. NRL; NRL-Pla; NRL-RP; NRL-RP-Pla; NRL-Ag; NRL-RP-Ag after 1, 2 and 7 days ADSCs cellular incubation. 
(a)

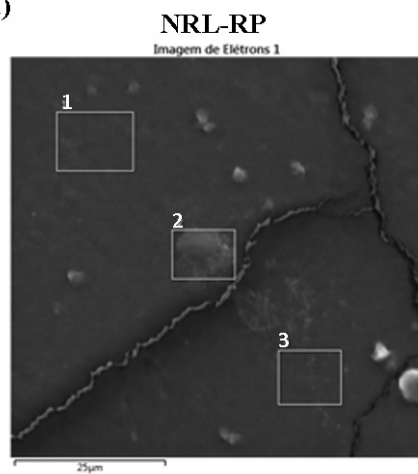

(b)

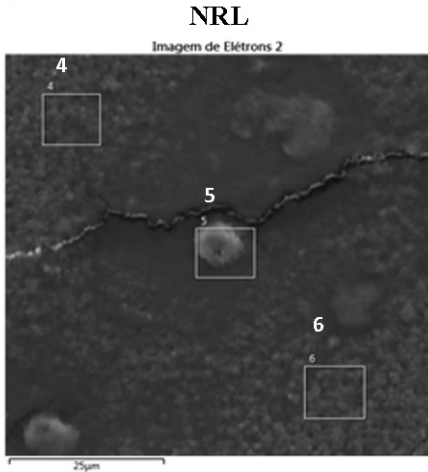

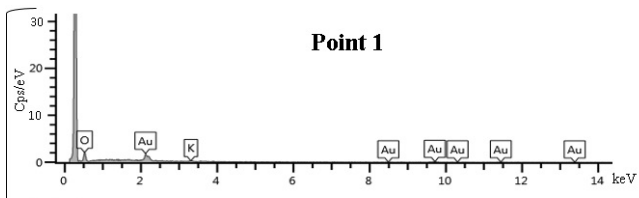

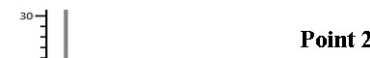

窝
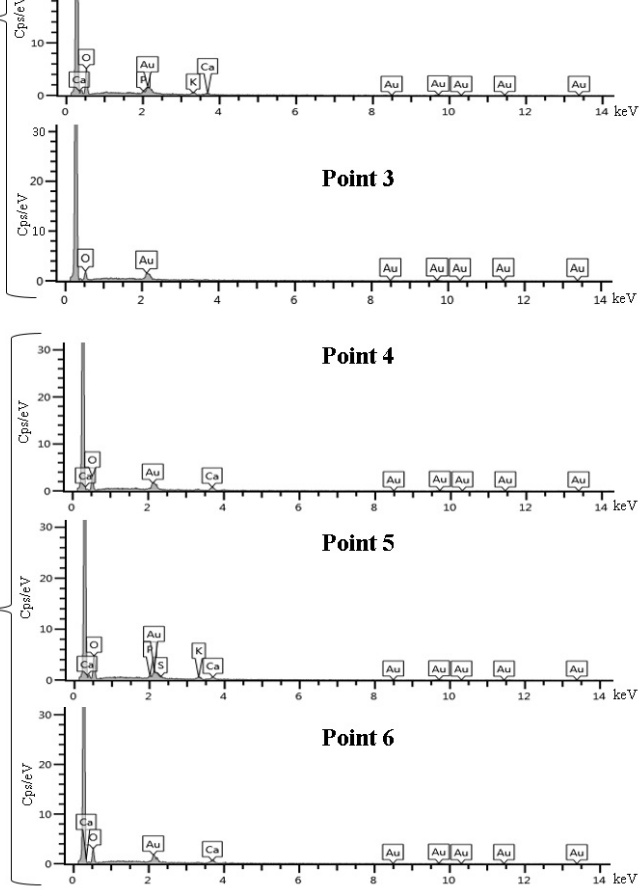

Figure 10. Elemental analysis through energy dispersive spectroscopy (EDS) micrographs: (a) NRL-RP and (b) NRL.

\section{Conclusions}

From the carried-out analyses, it is possible to conclude that plasma treatment associated with silver deposition and RP incorporation on the surfaces of the NRL films modifies their wettability, providing hydrophilic features, which in turn make them more suitable for biomedical application. Also, it was confirmed that these films could be stored and used up to several months after production, as hydrophobicity becomes a dominant feature on their surfaces over time.

Furthermore, the ATR-FTIR spectra showed that RP was physically incorporated into the NRL matrix, being a favorable condition to its release into the wound environment. The amount of deposited silver was calculated through RBS spectrum, indicating also that the metal is possibly found in the form of nanoparticles, and not in a film structure.

The results also allowed the association of factors like contact angle reduction and cellular dispersion over the films. It is possible that cells prefer hydrophilic surfaces, however, the presence of nonpolar functional groups most likely explains the little adsorption and the morphological aspect of the cells, which lost their fibroblast morphological characteristics. In this context, it was verified that the RPcontaining samples and those that received plasma treatment and silver deposition presented greater cell adhesion. In addition, these processes were effective in eliminating microorganisms, thus sterilizing the samples.
The immortalized L929 cell line and ADSCs collected from patients showed similar cytotoxicity patterns. Overall, the direct cell viability assays pointed out to moderate cytotoxicity and the indirect assays presented a cell viability percentage for all films and all extract concentrations above $70 \%$, demonstrating international safety standards.

The properties of the in vitro studies materials were satisfactory, once their aimed application is related to a wound dressing, avoiding cellular adhesion, i.e., not promoting cellular tear off from the affected site. Besides, it is desired that the films present hydrophilic features to drain excess exudate formed from the wound, while not being toxic. However, it must be highlighted that these findings instigate further research so that the films can be applied as protective and regenerating occlusive skin dressings.

The application of autologous ADSCs with enhanced NRL-based on RP extracts and silver materials for regenerating applications, presents advantageous as occlusive dressings for several skin defects.

\section{Acknowledgments}

The authors are grateful to the Programa de Pós Graduação em Ciência e Engenharia dos Materiais (PPGMAT-UCS), Programa de Pós Graduação em Biotecnologia (PPGBIOUCS), Universidade de Caxias do Sul (UCS), Laboratório de 
Implantação Iônica da Universidade Federal do Rio Grande do Sul (UFRGS), CNPq and CAPES.

\section{References}

1. WHO: World Health Organization. Facts about injuries: burn [cited 2020 June 3]. Geneva: WHO; 2020. Available from: http://www.who.int/mediacentre/factsheets/fs365/en/

2. Smeltzer SC. Brunner \& Suddarth: tratado de enfermagem médico-cirúrgica. 12. ed. São Paulo: Guanabara; 2011.

3. Jayadevan J, Alex R, Gopalakrishnapanicker U. Deproteinised natural rubber latex grafted poly(dimethylaminoethyl methacrylate) - poly(vinyl alcohol) blend membranes: synthesis, properties and application. Int J Biol Macromol. 2018;107(Pt B):1821-34. http://dx.doi.org/10.1016/j.ijbiomac.2017.10.042. PMid:29032213.

4. Rippel MM, Bragança FDC. Borracha natural e nanocompositos com argila. Quim Nova. 2009;32(3):818-26. http://dx.doi. org/10.1590/S0100-40422009000300024.

5. Herculano RD, Silva CP, Ereno C, Guimaraes SAC, Kinoshita A, Graeff CFO. Natural rubber latex used as drug delivery system in guided bone regeneration (GBR). Mater Res. 2009;12(2):2536. http://dx.doi.org/10.1590/S1516-14392009000200023.

6. Rempel LCT, Tizzot MRPA, Vasco JFM. Incidência de infecções bacterianas em pacientes queimados sob tratamento em hospital universitário de Curitiba. Rev Bras Queimaduras. 2011;10:3-9.

7. Hinrichsen SL. DIP: doenças infecciosas e parasitária. São Paulo: Guanabara; 2005.

8. Bonet CM, Lozano SA, Gatius JR. Prevalencia de infección por Staphylococcus aureus resistente a meticilina en heridas crónicas en atención primaria de Lleida. Estudio retrospectivo. Gerokomos. 2015;26:157-61.

9. Cabral ISR, Oldoni TLC, Prado A, Bezerra RMN, Alencar SM, Ikegaki M, et al. Composição fenólica, atividade antibacteriana e antioxidante da própolis vermelha brasileira. Quim Nova. 2009;32(6):1523-7. http://dx.doi.org/10.1590/ S0100-40422009000600031.

10. Valente MJ, Baltazar AF, Henrique R, Estevinho L, Carvalho M. Biological activities of Portuguese propolis: protection against free radical-induced erythrocyte damage and inhibition of human renal cancer cell growth in vitro. Food Chem Toxicol. 2011;49(1):86-92. http://dx.doi.org/10.1016/j.fct.2010.10.001. PMid:20934479.

11. Dos Santos HC, Vieira DS, Yamamoto SM, et al. Antimicrobial activity of propolis extract fractions against Staphylococcus spp. Isolated from goat mastitis. Pesq Vet Bras. 2019;39(12):954-60. http://dx.doi.org/10.1590/1678-5150-pvb-5940.

12. Krupp T, dos Santos BD, Gama LA, Silva JR, Arrais-Silva WW, de Souza NC, et al. Natural rubber - propolis membrane improves wound healing in second-degree burning model. Int J Biol Macromol. 2019;131:980-8. http://dx.doi.org/10.1016/j. ijbiomac.2019.03.147. PMid:30910673.

13. Bueno-Silva B, Marsola A, Ikegaki M, Alencar SM, Rosalen PL. The effect of seasons on Brazilian red propolis and its botanical source: chemical composition and antibacterial activity. Nat Prod Res. 2017;31(11):1318-24. http://dx.doi.org/10.1080/14 786419.2016.1239088. PMid:27701899.

14. Silva-Beltrán NP, Balderrama-Carmona AP, Umsza-Guez MA, Souza Machado BA. Antiviral effects of Brazilian green and red propolis extracts on Enterovirus surrogates. Environ Sci Pollut Res Int. 2020;27(23):28510-7. http://dx.doi.org/10.1007/ s11356-019-07458-z. PMid:31889278.

15. Frozza CO, Garcia CS, Gambato G, de Souza MD, Salvador $\mathrm{M}$, Moura S, et al. Chemical characterization, antioxidant and cytotoxic activities of Brazilian red propolis. Food Chem Toxicol. 2013;52:137-42. http://dx.doi.org/10.1016/j.fct.2012.11.013. PMid:23174518.
16. Loza K, Diendorf J, Sengstock C, Ruiz-Gonzalez L, GonzalezCalbet JM, Vallet-Regi M, et al. The dissolution and biological effects of silver nanoparticles in biological media. J Mater Chem B Mater Biol Med. 2014;2(12):1634-43. http://dx.doi. org/10.1039/c3tb21569e. PMid:32261391.

17. Yang Y, Bechtold T, Redl B, Caven B, Hu H. A novel silvercontaining absorbent wound dressing based on spacer fabric. J Mater Chem B Mater Biol Med. 2017;5(33):6786-93. http:// dx.doi.org/10.1039/C7TB01286A. PMid:32264328.

18. Khansa I, Schoenbrunner AR, Kraft CT, Janis JE. Silver in wound care - friend or foe?: A comprehensive review. Plast Reconstr Surg Glob Open. 2019;7(8):e2390. http://dx.doi. org/10.1097/GOX.0000000000002390. PMid:31592393.

19. Prestes MA, Ribas CAPM, Ribas JM Fo, Moreira LB, Boldt $\mathrm{AB}$, Brustolin $\mathrm{EV}$, et al. Wound healing using ionic silver dressing and nonocrystalline silver dressing in rats. Acta Cir Bras. 2012;27(11):761-7. http://dx.doi.org/10.1590/S010286502012001100004. PMid:23117607.

20. Silver S, Phung LT, Silver G. Silver as biocides in burn and wound dressings and bacterial resistance to silver compounds. J Ind Microbiol Biotechnol. 2006;33(7):627-34. http://dx.doi. org/10.1007/s10295-006-0139-7.

21. Gama-Lara SA, Pérez Mendoza MS, Vilchis-Nestor AR, Natividad R. Bionanotechnology: silver nanoparticles supported on bovine bone powder used as bactericide. Materials (Basel). 2020;13(2):462. http://dx.doi.org/10.3390/ma13020462. PMid:31963660.

22. Khémiri I, Essghaier B, Sadfi-Zouaoui N, Bitri L. Antioxidant and antimicrobial potentials of seed oil from Carthamus tinctorius L. in the management of skin injuries. Oxid Med Cell Longev. 2020;2020:4103418. http://dx.doi.org/10.1155/2020/4103418. PMid:33204394.

23. Iravani S, Korbekandi H, Mirmohammadi SV, Zolfaghari B. Synthesis of silver nanoparticles: chemical, physical and biological methods. Res Pharm Sci. 2014;9(6):385-406. PMid:26339255.

24. Chen L, Peng X. Silver nanoparticle decorated cellulose nanofibrous membrane with good antibacterial ability and high water permeability. Appl Mater Today. 2017;9:130-35.

25. Wentao W, Tao Z, Bulei S, Tongchang Z, Qicheng Z, Fan W et al. Functionalization of polyvinyl alcohol composite film wrapped in am-ZnO-CuO-Au nanoparticles for antibacterial application and wound healing. Appl Mater Today. 2019;17:36-44.

26. Kimura VT, Miyasato CS, Genesi BP, Lopes PS, Yoshida CMP, Silva CF. The effect of andiroba oil and chitosan concentration on the physical properties of chitosan emulsion film. Polímeros. 2016;26(2):168-75. http://dx.doi.org/10.1590/0104-1428.2013.

27. Depan D, Misra RDK. Hybrid nanoscale architecture of wound dressing with super hydrophilic, antimicrobial, and ultralow fouling attributes. J Biomed Nanotechnol. 2015;11(2):308-18. http://dx.doi.org/10.1166/jbn.2015.1908. PMid:26349306.

28. Archana D, Dutta J, Dutta PK. Evaluation of chitosan nano dressing for wound healing: Characterization, in vitro and in vivo studies. Int J Biol Macromol. 2013;57:193-203. http:// dx.doi.org/10.1016/j.ijbiomac.2013.03.002. PMid:23518244.

29. Eswaramoorthy N, McKenzie DR. Plasma treatments of dressings for wound healing: a review. Biophys Rev. 2017;9(6):895-917. http://dx.doi.org/10.1007/s12551-017-0327-x. PMid:28971326.

30. Zadeh HH, Joupari MD, Sahebalzamani MA. Physicochemicaland biocompatibility of oxygen and nitrogen plasma treatment using a PLA scaffold. AIP Adv. 2020;10:125205.

31. Alemán C, Fabregat G, Armelin E, Buendía JJ, Llorca J. Plasma surface modification of polymers for sensor applications. $\mathrm{J}$ Mater Chem B Mater Biol Med. 2018;6(41):6515-33. http:// dx.doi.org/10.1039/C8TB01553H. PMid:32254860.

32. Macêdo MOC, Macêdo HRA, Barbosa JCP, et al. Perfil da molhabilidade em membranas de quitosana tratadas por plasma de hidrogênio. Mater e. 2010;3:12-6. 
33. Rodrigues MM, Fontoura CP, Garcia CSC, Martins ST, Henriques JAP, Figueroa CA, et al. Investigation of plasma treatment on UHMWPE surfaces: impact on physicochemical properties, sterilization and fibroblastic adhesion. Mater Sci Eng C Mater Biol Appl. 2019;102:264-75. http://dx.doi.org/10.1016/j. msec.2019.04.048. PMid:31146999.

34. Walker NJ, Rebowe RE, Allred L, Craig CK, Williams J, Holmes JH 4th, et al. 77 initial experience with autologous cell suspension for treatment of partial thickness facial burns. J Burn Care Res. 2018;39(Suppl 1):43-4. http://dx.doi.org/10.1093/ jbcr/iry006.080.

35. Schmelzer E, McKeel DT, Gerlach JC. Characterization of Human Mesenchymal Stem Cells from Different Tissues and Their Membrane Encasement for Prospective Transplantation Therapies. BioMed Res Int. 2019;5:1-13. http://dx.doi. org/10.1155/2019/6376271. PMid:30941369.

36. da Silva LP, Reis RL, Correlo VM, Marques AP. Hydrogel-Based Strategies to Advance Therapies for Chronic Skin Wounds. Annu Rev Biomed Eng. 2019;21(1):145-69. http://dx.doi. org/10.1146/annurev-bioeng-060418-052422. PMid:30822099.

37. Zhou ZQ, Chen Y, Chai M, Tao R, Lei YH, Jia YQ, et al. Adipose extracellular matrix promotes skin wound healing by inducing the differentiation of adipose-derived stem cells into fibroblasts. Int J Mol Med. 2019;43(2):890-900. PMid:30535488.

38. Agostini D. Caracterização dos constituintes do látex e da borracha natural que estimulam a angiogênese [dissertação]. Presidente Prudente: Universidade Estadual Paulista; 2009.

39. Reis R, Dumée LF, Merenda A, Orbell JD, Schütz JA, Duke MC. Plasma-induced physicochemical effects on a poly(amide) thin-film composite membrane. Desalination. 2017;403:3-11. http://dx.doi.org/10.1016/j.desal.2016.06.009.

40. Zuk PA, Zhu M, Ashjian P, De Ugarte DA, Huang JI, Mizuno $\mathrm{H}$, et al. Human adipose tissue is a source of multipotent stem cells. Mol Biol Cell. 2002;13(12):4279-95. http://dx.doi. org/10.1091/mbc.e02-02-0105. PMid:12475952.

41. Dominici M, Le Blanc K, Mueller I, Slaper-Cortenbach I, Marini F, Krause D, et al. Minimal criteria for defining multipotent mesenchymal stromal cells. The International Society for Cellular Therapy position statement. Cytotherapy. 2006;8(4):315-7. http:// dx.doi.org/10.1080/14653240600855905. PMid:16923606.

42. ISO: International Standards Organization. ISO 10993-5:2009. Biological evaluation of medical devices. Biological evaluation of medical devices - Part 5: Tests for in vitro cytotoxicity. Geneva: ISO; 2009.

43. ISO: International Standards Organization. EN-ISO-10993-12. Biological evaluation of medical devices - Part 12: Sample preparation and reference materials. Geneva: ISO; 2004.

44. Denizot F, Lang R. Rapid colorimetric assay for cell growth and survival. Modifications to the tetrazolium dye procedure giving improved sensitivity and reliability. J Immunol Methods. 1986;89(2):271-7. http://dx.doi.org/10.1016/0022-1759(86)903686. PMid:3486233.

45. Fotakis G, Timbrell JA. In vitro cytotoxicity assays: comparison of LDH, neutral red, MTT and protein assay in hepatoma cell lines following exposure to cadmium chloride. Toxicol Lett. 2006;160(2):171-7. http://dx.doi.org/10.1016/j.toxlet.2005.07.001. PMid:16111842.

46. Zancanela DC, Funari CS, Herculano RD, Mello VM, Rodrigues $\mathrm{CM}$, Borges FA, et al. Natural rubber latex membranes incorporated with three different types of propolis: physical-chemistry and antimicrobial behaviours. Mater Sci Eng C Mater Biol App. 2019;97:576-82. http://dx.doi.org/10.1016/j.msec.2018.12.042. PMid:30678944.

47. Zancanela DC, Herculano RD, Funari CS, Marcos CM, Almeida AMF, Guastaldi AC. Physical, chemical and antimicrobial implications of the association of propolis with a natural rubber latex membrane. Mater Lett. 2017;209:39-42. http://dx.doi. org/10.1016/j.matlet.2017.07.093.
48. Ribeiro JA, Rosa SRF, Leite CRM, Vasconcelos CL, Soares JM. Development assessment of natural latex membranes: A new proposal for the treatment of amblyopia. Mater Res. 2017;20(3):653-60. http://dx.doi.org/10.1590/1980-5373$\mathrm{mr}-2016-0355$

49. Rolere S, Liengprayoon S, Vaysse L, Sainte-Beuve J, Bonfils F. Investigating natural rubber composition with Fourier Transform Infrared (FT-IR) spectroscopy: A rapid and nondestructive method to determine both protein and lipid contents simultaneously. Polym Test. 2015;43:83-93. http://dx.doi. org/10.1016/j.polymertesting.2015.02.011.

50. Silva AJ, Silva JR, De Souza NC, Souto PCS. Membranes from latex with propolis for biomedical applications. Mater Lett. 2014;116:235-8. http://dx.doi.org/10.1016/j.matlet.2013.11.045.

51. Oliveira KA M, Oliveira GV, Batalini C, Rosalem JA, Ribeiro LS. Atividade antimicrobiana e quantificação de Flavonoides e Fenóis totais em diferentes extratos de Própolis. Semin Cienc Biol Saude. 2013;33(2):211-22. http://dx.doi.org/10.5433/16790367.2012v33n2p211.

52. do Nascimento TG, da Silva PF, Azevedo LF, da Rocha LG, de Moraes Porto IC, Lima E Moura TF, et al. Polymeric Nanoparticles of Brazilian Red Propolis Extract: Preparation, Characterization, Antioxidant and Leishmanicidal Activity. Nanoscale Res Lett. 2016;11(1):301-16. http://dx.doi.org/10.1186/ s11671-016-1517-3. PMid:27316742.

53. Bois L, Chassagneux F, Parola S, Bessueille F, Battie Y, Destouches N, et al. Growth of ordered silver nanoparticles in silica film mesostructured with a triblock copolymer PEOPPO-PEO. J Solid State Chem. 2009;182(7):1700-7. http:/ dx.doi.org/10.1016/j.jssc.2009.01.044.

54. Schneidewind H, Schüler T, Strelau KK, Weber K, Cialla D, Diege $\mathrm{M}$, et al. The morphology of silver nanoparticles prepared by enzyme-induced reduction. Beilstein J Nanotechnol. 2012;3:40414. http://dx.doi.org/10.3762/bjnano.3.47. PMid:23016145.

55. Santos DASG. Preparação e caracterização de nanopartículas de metais nobres pelo método de agregação gasosa [dissertação] São Paulo: Universidade de São Paulo; 2018. http://dx.doi org/10.11606/D.43.2018.tde-22102018-031310.

56. Arvidsson R, Molander S, Sandén BA. Impacts of a silvercoated future. J Ind Ecol. 2011;15(6):844-54. http://dx.doi. org/10.1111/j.1530-9290.2011.00400.x.

57. Rigo C, Roman M, Munivrana I, Vindigni V, Azzena B, Barbante $\mathrm{C}$, et al. Characterization and evaluation of silver release from four different dressings used in burns care. Burns. 2012;38(8):1131-42. http://dx.doi.org/10.1016/j.burns.2012.06.013. PMid:22985973.

58. Cohen MS, Stern JM, Vanni AJ, Kelley RS, Baumgart E, Field $\mathrm{D}$, et al. In vitro analysis of a nanocrystalline silver-coated surgical mesh. Surgical Infections. 2007;8(3):397-404. http:// dx.doi.org/10.1089/sur.2006.032.

59. de Farias ME. Aspectos fisiológicos da produção de látex de seringueiras cultivadas em nepomuceno - MG. Lavras: Universidade Federal de Lavras; 2017.

60. Sanchis MR, Blanes V, Blanes M, Garcia D, Balart R. Surface modification of low density polyethylene (LDPE) film by low pressure O2 plasma treatment. Eur Polym J. 2006;42(7):155868. http://dx.doi.org/10.1016/j.eurpolymj.2006.02.001.

61. Li JH, Shao XS, Zhou Q, Li M-Z, Zhang Q-Q. The double effects of silver nanoparticles on the PVDF membrane: surface hydrophilicity and antifouling performance. Appl Surf Sci. 2013;265:663-70. http://dx.doi.org/10.1016/j.apsusc.2012.11.072.

62. Long SF, Clarke S, Davies MC, Lewis AL, Hanlon GW, Lloyd AW. Controlled biological response on blends of a phosphorylcholine-based copolymer with poly(butyl methacrylate). Biomaterials. 2003;24(23):4115-21. http://dx.doi.org/10.1016/ S0142-9612(03)00272-2. PMid:12853241.

63. Van Dongen MHA, Verkuijlen ROF, Aben R, Bernards JPC. Wettability and aging of polymer substrates after atmospheric dielectrical barrier discharge plasma on demand treatment. J 
Imaging Sci Technol. 2013;57(3):1-5. http://dx.doi.org/10.2352/J. ImagingSci.Technol.2013.57.3.030503.

64. Banik I, Kim KS, Yun Y, Kim DH, Ryu CM, Park CS, et al. A closer look into the behavior of oxygen plasma-treated highdensity polyethylene. Polymer (Guildf). 2003;44(4):1163-70. http://dx.doi.org/10.1016/S0032-3861(02)00847-9.

65. Zille A, Fernandes MM, Francesko A, Tzanov T, Fernandes M, Oliveira FR, et al. Size and aging effects on antimicrobial efficiency of silver nanoparticles coated on polyamide fabrics activated by atmospheric DBD plasma. ACS Appl Mater Interfaces. 2015;7(25):13731-44. http://dx.doi.org/10.1021/ acsami.5b04340. PMid:26057400.

66. Yüce MY, Demirel AL. The effect of nanoparticles on the surface hydrophobicity of polystyrene. Eur Phys J B. 2008;64(34):493-7. http://dx.doi.org/10.1140/epjb/e2008-00042-0.

67. An YH, Alvi FI, Kang Q, Laberge M, Drews MJ, Zhang J, et al. Effects of sterilization on implant mechanical property and biocompatibility. Int J Artif Organs. 2005;28(11):1126-37. http:// dx.doi.org/10.1177/039139880502801110. PMid:16353119.

68. Qiu QQ, Sun WQ, Connor J. Sterilization of biomaterials of synthetic and biological origin. In: Ducheyne P, editor. Comprehensive biomaterials II. USA: Elsevier; 2017. http:// dx.doi.org/10.1016/B978-0-12-803581-8.10186-9.

69. Muhl S, Pérez A. The use of hollow cathodes in deposition processes: a critical review. Thin Solid Films. 2015;579:17498. http://dx.doi.org/10.1016/j.tsf.2015.02.066.

70. Jin SH, Lee JE, Yun JH, Kim I, Ko Y, Park JB. Isolation and characterization of human mesenchymal stem cells from gingival connective tissue. J Periodontal Res. 2015;50(4):461-7. http:// dx.doi.org/10.1111/jre.12228. PMid:25229614.

71. Trubiani O, Zalzal SF, Paganelli R, Marchisio M, Giancola R, Pizzicannella J, et al. Expression profile of the embryonic markers nanog, OCT-4, SSEA-1, SSEA-4, and Frizzled-9 receptor in human periodontal ligament mesenchymal stem cells. J Cell Physiol. 2010;225(1):123-31. http://dx.doi.org/10.1002/ jcp.22203. PMid:20458727.

72. Pittenger MF, Mackay AM, Beck SC, Jaiswal RK, Douglas $\mathrm{R}$, Mosca JD, et al. Multilineage potential of adult human mesenchymal stem cells. Science. 1999;284(5411):143-7.

73. Mafi R, Hindocha S, Mafi P, Griffin M, Khan WS. Sources of adult mesenchymal stem cells applicable for musculoskeletal applications - a systematic review of the literature. Open Orthop J. 2011;5(1, Suppl 2):242-8. http://dx.doi.org/10.2174/187432 5001105010242. PMid:21886689.

74. Hassan WU, Greiser U, Wang W. Role of adipose-derived stem cells in wound healing. Wound Repair Regen. 2014;22(3):31325. http://dx.doi.org/10.1111/wrr.12173. PMid:24844331.

75. Lotfi M, Naderi-Meshkin H, Mahdipour E, Mafinezhad A, Bagherzadeh R, Sadeghnia HR, et al. Adipose tissue-derived mesenchymal stem cells and keratinocytes co-culture on gelatin/chitosan/ $\beta$-glycerol phosphate nanoscaffold in skin regeneration. Cell Biol Int. 2019;43(12):1-14. http://dx.doi. org/10.1002/cbin.11119. PMid:30791186.

76. McCarthy ME, Brown TA, Bukowska J, Bunnell BA, Frazier $\mathrm{T}, \mathrm{Wu} \mathrm{X}$, et al. Therapeutic applications for adipose-derived stem cells in wound healing and tissue engineering. Curr Stem Cell Rep. 2018;4(2):127-37. http://dx.doi.org/10.1007/s40778018-0125-9.

77. Watthanaphanit A, Rujiravanit R. Sericin-binded-deprotenized natural rubber film containing chitin whiskers as elasto-gel dressing. Int J Biol Macromol. 2017;101:417-26. http://dx.doi. org/10.1016/j.ijbiomac.2017.03.094. PMid:28322960.
78. Pichayakorn W, Boonme P, Taweepreda W. Preparation of peel-off mask from deproteinized natural rubber latex. Adv Mat Res. 2013;747:95-8. http://dx.doi.org/10.4028/www.scientific. net/AMR.747.95.

79. Picolotto A, Pergher D, Pereira GP, Machado KG, da Silva Barud H, Roesch-Ely M, et al. Bacterial cellulose membrane associated with red propolis as phytomodulator: improved healing effects in experimental models of diabetes mellitus. Biomed Pharmacother. 2019;112:1-10. http://dx.doi.org/10.1016/j. biopha.2019.108640. PMid:30784929.

80. Garms BC, Borges FA, de Barros NR, Marcelino MY, Leite MN, Del Arco MC, et al. Novel polymeric dressing to the treatment of infected chronic wound. Appl Microbiol Biotechnol. 2019;103(12):4767-78. http://dx.doi.org/10.1007/s00253-01909699-x. PMid:31065753.

81. Maria PSMSS, Vidal BC, Haun M, Durán N. Violacein cytotoxicity and induction of apoptosis in V79 cells. Vitr Cell Dev Biol - Anim 2000;36(8):539-43.

82. Pusnik M, Imeri M, Deppierraz G, Bruinink A, Zinn M. The agar diffusion scratch assay - A novel method to assess the bioactive and cytotoxic potential of new materials and compounds. Sci Rep. 2016;6(1):1-10. http://dx.doi.org/10.1038/srep20854. PMid:26861591.

83. Tong W, Tran PA, Turnley AM, Aramesh M, Prawer S, Brandt $\mathrm{M}$, et al. The influence of sterilization on nitrogen-included ultrananocrystalline diamond for biomedical applications. Mater Sci Eng C Mater Biol Appl. 2016;61:324-32. http:// dx.doi.org/10.1016/j.msec.2015.12.041. PMid:26838856.

84. Juan-Díaz MJ, Martínez-Ibáñez M, Lara-Sáez I, da Silva S, Izquierdo R, Gurruchaga M, et al. Development of hybrid sol-gel coatings for the improvement of metallic biomaterials performance. Prog Org Coat. 2016;96:42-51. http://dx.doi. org/10.1016/j.porgcoat.2016.01.019.

85. Liu XL, Zhou WR, Wu YH, Cheng Y, Zheng YF. Effect of sterilization process on surface characteristics and biocompatibility of pure $\mathrm{Mg}$ and $\mathrm{MgCa}$ alloys. Mater Sci Eng C Mater Biol Appl. 2013;33(7):4144-54. http://dx.doi.org/10.1016/j.msec.2013.06.004. PMid:23910326.

86. Nascimento RMD, Ramos SMM, Bechtold IH, Hernandes AC. Wettability study on natural rubber surfaces for applications as biomembranes. ACS Biomater Sci Eng. 2018;4(8):2784-93. http:// dx.doi.org/10.1021/acsbiomaterials.8b00723. PMid:33435003.

87. Bauer S, Schmuki P, von der Mark K, Park J. Engineering biocompatible implant surfaces: Part I: materials and surfaces. Prog Mater Sci. 2013;58(3):261-326. http://dx.doi.org/10.1016/j. pmatsci.2012.09.001

88. Nawamawat K, Sakdapipanich JT, Ho CC, Ma Y, Song J, Vancso JG. Surface nanostructure of Hevea brasiliensis natural rubber latex particles. Colloids Surf A Physicochem Eng Asp. 2011;390(1-3):157-66. http://dx.doi.org/10.1016/j. colsurfa.2011.09.021

89. Blackley DC. Polymer latices science and technology. Vol. 2. USA: Springer; 1997.

90. do Nascimento RM, de Paula AJ, Oliveira NC, Alves AC, de Oliveira Aquino YML, Souza AG Fo, et al. Towards the production of natural rubber-calcium phosphate hybrid for applications as bioactive coatings. Mater Sci Eng C Mater Biol Appl. 2019;94:417-25. http://dx.doi.org/10.1016/j. msec.2018.09.048. PMid:30423725.

91. d'Auzac J. Physiology of rubber tree latex the laticiferous cell and latex-a model of cytoplasm. Boca Raton: CRC Press; 2018. 